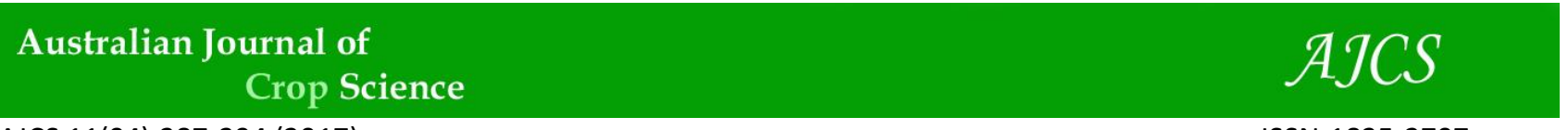

AJCS 11(04):387-394 (2017)

ISSN:1835-2707

doi: 10.21475/ajcs.17.11.04.pne208

\title{
Biomass and morphological parameters of lemon verbena (Aloysia triphylla) under different shading levels during different seasonal conditions
}

\author{
Denise Schmidt ${ }^{1}$, Braulio Otomar Caron ${ }^{1}$, Nadia Regina Volpato Menegat ${ }^{1}$, Elvis Felipe Elli ${ }^{2 *}$, John \\ Robert Stolzle $^{1}$, Felipe Schwerz ${ }^{1}$, Elder Eloy ${ }^{3}$, Jaqueline Sgarbossa ${ }^{1}$, Daiane Prochnow ${ }^{1}$ \\ ${ }^{1}$ Department of Agronomic Sciences, Federal University of Santa Maria, Frederico Westphalen Campus, 98400- \\ 000, Frederico Westphalen, Rio Grande do Sul, Brazil \\ ${ }^{2}$ Department of Biosystems Engineering, University of São Paulo, College of Agriculture, Av. Pádua Dias 11, \\ 13418-900, Piracicaba, SP, Brazil \\ ${ }^{3}$ Department of Forest Engineering, Federal University of Santa Maria, Frederico Westphalen Campus, 98400- \\ 000, Frederico Westphalen, Rio Grande do Sul, Brazil
}

*Corresponding author: elvisfelipeelli@yahoo.com

\begin{abstract}
Shading greenhouse may be an effective method to achieve a suitable environment for crop growth in subtropical regions. The aim of this study was to evaluate the production of leaves and branches as well as the morphological parameters of height and leaf area of the species Aloysia triphylla, under different shading levels throughout the seasons of the year. A randomized block design in factorial scheme $3 \times 4 \times 6$, i.e., three levels of shading $(0 \%, 30 \%$ and $50 \%)$, four seasons (summer, autumn, winter and spring) and six collection in each season $(15,30,45,60,75$ and 90 days after the beginning of each season), with four replications, was used. All evaluations were performed in 2012, since in the first evaluation (summer) the plants had 65 days after transplanting and the last evaluation (spring) the plants had 315 days after transplanting. The dry matter of leaves and branches, leaf area, and plant height were evaluated. The production of the dry matter of leaves and branches, and height and leaf area for the species Aloysia triphylla is influenced by shading levels and the seasons of the year. The variables are highly dependent on the seasonality of meteorological elements such as temperature, solar radiation, rainfall, and frost. In an environment with $0 \%$ shading, the dry matter production of leaves was $60.8 \%$ higher in the spring, than those observed for the $30 \%$ and $50 \%$ of shading, while this levels resulted higher production in the summer. We showed that the use of shading screens in order to attenuate the solar radiation in places or seasons where there is high light intensity is an effective method to achieve higher production of leaves, which is important source for the oil production.
\end{abstract}

Received 17 June 2016; Revised 23 Dec 2016; Accepted 20 Feb 2017.

Keywords: medicinal plant, solar radiation, leaf area, photosynthetic rate, meteorological elements.

Abbreviations: DABS_days after the beginning of the season, DBM_dry branch matter, DLM_dry leaf matter, LA_leaf area, SR_solar radiation.

\section{Introduction}

The medicinal species Aloysia triphylla belongs to the Lamiaceae family which has more than 100 genera distributed in tropical and subtropical regions of the world. The plant is classified as an astringent and aromatic herb, rich in volatile oil, which acts as a mild sedative. The economic interest of this species is mainly with regards to the commercial extraction of essential oil from the leaves of the plant; the essential oil has a high market value due to its use by various industries, especially the pharmaceutical and perfume industries (Lorenzi and Matos, 2002; Duarte et al., 2007).

Seasonality can have an extreme impact on plant growth and development. Among the meteorological elements of great importance for plant growth, air temperature, and solar radiation are the two most important. Values of these elements below or above the conditions required by plants can compromise the expression and maximum growth potential of a given plant (Pinto and Bertolucci, 2002).

Incident solar radiation and its interception by the plant canopy triggers the process of photosynthesis; in this context, the interactions that occur in the canopy of plants are associated with the amount of incident solar radiation. The radiation that arrives at a canopy of a plant can significantly modify the production of biomass, plant height, and leaf area index (Cockshull et al., 1992).

Changes in the solar radiation of a given environment may affect the photosynthetic apparatus of plants. Low solar radiation available reduces the photosynthetic rate and hence plant growth. Radiation levels above the light saturation point inhibit enzymes of the Calvin-Benson cycle that follow ATP and NADPH production, which originates from light reactions, in addition to causing photoinhibition due to an excess of energy in the reaction center of photosystem II. As a result of this, we can identify the reduction of quantum efficiency, photosynthetic rate, and possible damage to the photosynthetic apparatus (Zhang et al., 2006; Murchie et al., 2008; Taiz and Zeiger, 2013). Research showing the change of yield, and vegetative growth traits as a function of incident 
solar radiation, both as suboptimal and optimal levels were showed by Bianculli et al. (2016); Cossu et al. (2014); Dario et al. (2015); Kataria and Guruprasad (2015). Caron et al. (2014A) reported that the intensity of photosynthetically active solar radiation modifies the physiological behavior (stomatal conductance and transpiration), which causes a variation in the metabolic activity of the plant. Similarly Elli et al. (2013) found that these physiological variables may influence plant development. The amount of radiation can change the value of metabolic compounds presents in the plant (Suarez et al., 2003).

As winter approaches, the average values of solar radiation will decrease, below the point at which a plant will photosynthesize (Buriol et al., 2000). Plants that are adapted to warm seasons tend to restrict their growth outside of these ideal environmental conditions. Studies have been conducted with the Aloysia triphylla species (Brant et al., 2010; Paulus et al., 2013; Zeppenfeld et al., 2014; Ebadi et al., 2015; Dianat et al., 2016), since the species has aroused economic interest in the exploration of compounds with therapeutic properties.

Information that reveals the impact of season of the year and shading conditions on the Aloysia triphylla responses are not found in the literature, and considering the economic interest in the exploration of compounds with therapeutic properties new researches with this species are needed. In addressing this lack of information, the study aimed to identify the season and shading conditions most favorable for the vegetative growth of Aloysia triphylla, as this growth directly relates to the production of essential oil. In order to accomplish the goals of this study, the production of leaf and branch biomass, and morphological parameters such as height and leaf area were evaluated for each treatment throughout different seasons of the year.

\section{Results and discussion}

\section{Meteorological characterization and analysis of variance}

The values of average monthly of maximum and minimum temperatures and of accumulated solar radiation at each level of shading observed from December 2011 to December 2012, showed variations throughout all seasons (Fig 1). It is important to note the irregularity of rainfall that occurred during the experiment, which presents monthly values between 19 to $327 \mathrm{~mm}$ for the months with the highest and lowest rainfall (May and October, respectively). According to the analysis of variance, it is possible to identify significant differences for all variables in the interaction: season of the year $\mathrm{x}$ collection; for the variables dry branch matter and dry leaf matter in interaction: season $\mathrm{x}$ shading. For dry branch matter, leaf area and plant height, in the interaction: collection $\mathrm{x}$ shading was analyzed.

The DLM in autumn season demonstrated the higher values compared to the collection winter corresponding to 15 DABS and then to the winter and summer in 30 days after the beginning on the season (Table 1). From this period, the stratification of the mean between the seasons of the year, became more apparent, i.e., lower values were found in winter toward the end of the seasons, while the summer was responsible for higher values. Similar variations in averages were observed for the DBM. The accumulated radiation and average temperature throughout the months were recorded and calculated: Summer $\left(2182 \mathrm{MJ} \mathrm{m}^{-2}\right.$ and $\left.24.60^{\circ} \mathrm{C}\right)$, autumn $\left(1237 \mathrm{MJ} \mathrm{m}^{-2}\right.$ and $\left.17.19^{\circ} \mathrm{C}\right)$, winter $\left(1167 \mathrm{MJ} \mathrm{m}^{-2}\right.$ and $\left.14.69^{\circ} \mathrm{C}\right)$, and spring $\left(1863 \mathrm{MJ} \mathrm{m}^{-2}\right.$ and $\left.20.67^{\circ} \mathrm{C}\right)$.
The shadings of 30 and $50 \%$ made resulted in the reduction of accumulated radiation 1528 and 1091 (summer); 866 and 619 (autumn); 817 and 584 (winter); 1304 and 932 (spring)

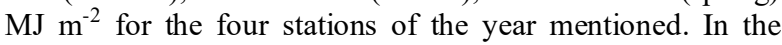
autumn, lower climatic extremes of temperatures were observed 1.2 (day 06), -2.2 (day 07), and $-1.2^{\circ} \mathrm{C}$ in on $08 / 06 / 2012$. In the same form, in the winter, an extreme value less than 0.9 was observed on the day $12 / 07 / 2012$. In this season, the occurrence of frost observed in the experimental area, could have potentially reduced the DLM and DBM values in the seasons of autumn and winter. The reduction in temperature and the availability of solar radiation, particularly from the month of April (Fig. 1), along with the occurrence of frost, likely influenced the LA in autumn season in the periods of 75 and 90 DABS and in the winter from 15 DABS. These factors may also have been responsible for reducing plant height in winter and spring up to the 75 DABS (Table 1). In addition to the frost, the previously described environmental conditions may have resulted in plant dormancy and the emission of new leaves and branches does not occur in these conditions (Taiz and Zeiger, 2013).

These results corroborate with the findings of Paulus et al. (2013), which affirmed that the plant Aloysia triphylla, in southern Brazil, begin the loss of its leaves in the months of May and June, arriving at a $40 \%$ reduction of total leaf mass. During the months of June and July, at the end of autumn and early winter season, with the occurrence of frost, leaf loss rates can reach $100 \%$.

\section{Effect of shading levels in the accumulation of dry matter}

In the interaction between shading $\mathrm{x}$ DABS (Table 2), the highest averages for DBM were found in $0 \%$ shading; this likely occurred due to the higher photosynthetic rates. In this context, Lopes et al. (1986) emphasize that the reduction in light intensity can often stay below the luminous point of saturation, thereby reducing photosynthetic rate and the production of dry biomass. Castro et al. (2005) emphasizes that the reverse may also occur, ie, the reduction of dry biomass in environment without shadowing, may be linked to photoinhibition, which can reduce the photosynthetic capacity of plants exposed to high levels of radiation, higher than those required to achieve a saturated luminous point.

This is one of the factors which can help explain the similar behavior between the shading levels at the time of collection $(15,45$, and 90 days). The reduction in radiation availability may have been partly compensated by increased levels of diffuse radiation which has the characteristic of being multidirectional, and so, is better able to penetrate the canopy of plants (Buriol et al., 1995). In this context, Caron et al. (2014b) found higher efficiency in the use of radiation in yerba mate plants in the understory for pine trees, likely due to diffuse fractioning of radiation, after being transmitted through the canopy for trees.

Higher values were observed when analyzing the LA (Table 2 ) in shaded environments in periods corresponding to 45 and 60 days. Garcez Neto et al. (2010) emphasized that the increase of specific leaf area in shadowed environments is associated to morphological acclimatization that plants perform in order to compensate for the light restriction. The plants can increase the reception of solar radiation that is transmitted through the shading mesh. Martins et al. (2008), studying Melissa officinalis, observed that plants grown in full sun had lower leaf area indices when compared to those cultivated in the shade. Meira et al. (2012), working with 
Table 1. Interactions between: season of the year $x$ days after the beginning of the season (DABS); shading levels $x$ DABS for the dry matter of leaves (DLM g plant ${ }^{-1}$ ), dry matter of branches (DBM g plant $\left.{ }^{-1}\right)$, leaf area (LA; $\mathrm{cm} \mathrm{plant}^{-1}$ ) and plant height $\left(\mathrm{cm}^{2}\right.$. Frederico Westphalen - RS, 2012.

\begin{tabular}{|c|c|c|c|c|c|c|c|c|c|c|c|c|c|}
\hline \multirow{2}{*}{ Var. } & \multirow{2}{*}{ Season } & \multicolumn{12}{|c|}{ Days after the beginning of the season (DABS) } \\
\hline & & 1 & & 30 & & 45 & & 60 & & 75 & & 90 & \\
\hline \multirow{4}{*}{ DLM } & Summer & 5.09 & $\mathrm{ab}$ & 11.54 & $\mathrm{bc}$ & 34.38 & $\mathrm{a}$ & 43.07 & $\mathrm{~b}$ & 63.45 & $\mathrm{a}$ & 96.03 & $\mathrm{a}$ \\
\hline & Autumn & 13.49 & $\mathrm{a}$ & 25.85 & $\mathrm{a}$ & 34.71 & $\mathrm{a}$ & 47.44 & $\mathrm{~b}$ & 43.76 & $\mathrm{~b}$ & 27.16 & $\mathrm{~d}$ \\
\hline & Winter & 2.74 & $\mathrm{~b}$ & 4.69 & $\mathrm{c}$ & 4.03 & $\mathrm{~b}$ & 5.03 & $\mathrm{c}$ & 9.20 & $\mathrm{c}$ & 9.78 & $\mathrm{c}$ \\
\hline & Spring & 5.25 & $a b$ & 18.00 & $a b$ & 34.98 & $\mathrm{a}$ & 58.99 & $\mathrm{a}$ & 55.16 & $\mathrm{a}$ & 58.52 & $\mathrm{~b}$ \\
\hline \multirow{4}{*}{ DBM } & Summer & 1.88 & $\mathrm{~b}$ & 7.93 & $\mathrm{bc}$ & 27.38 & $\mathrm{a}$ & 39.49 & $\mathrm{a}$ & 50.09 & $a$ & 69.61 & $\mathrm{a}$ \\
\hline & Autumn & 7.68 & $\mathrm{a}$ & 16.28 & $\mathrm{a}$ & 28.05 & $\mathrm{a}$ & 34.44 & $a b$ & 30.10 & $\mathrm{c}$ & 18.57 & $\mathrm{c}$ \\
\hline & Winter & 1.53 & $\mathrm{~b}$ & 3.52 & $\mathrm{c}$ & 4.81 & $\mathrm{~b}$ & 4.07 & $\mathrm{c}$ & 4.09 & $\mathrm{~d}$ & 7.99 & $\mathrm{~d}$ \\
\hline & Spring & 1.86 & $b$ & 12.91 & $a b$ & 5.53 & $\mathrm{~b}$ & 29.13 & $\mathrm{~b}$ & 38.28 & $\mathrm{~b}$ & 44.49 & $\mathrm{~b}$ \\
\hline \multirow{4}{*}{ LA } & Summer & 8.65 & $\mathrm{~b}$ & 25.35 & $\mathrm{~b}$ & 61.54 & $\mathrm{a}$ & 83.50 & $\mathrm{~b}$ & 119.12 & $a$ & 209.95 & $\mathrm{a}$ \\
\hline & Autumn & 24.07 & $\mathrm{a}$ & 52.57 & $\mathrm{a}$ & 59.32 & $\mathrm{a}$ & 101.03 & $\mathrm{a}$ & 71.00 & $\mathrm{c}$ & 55.57 & $\mathrm{c}$ \\
\hline & Winter & 6.48 & $\mathrm{~b}$ & 10.69 & $\mathrm{c}$ & 6.29 & $\mathrm{~b}$ & 9.43 & $\mathrm{c}$ & 5.59 & $\mathrm{~d}$ & 22.35 & $\mathrm{~d}$ \\
\hline & Spring & 8.31 & $\mathrm{~b}$ & 27.75 & b & 72.38 & $\mathrm{a}$ & 85.99 & $\mathrm{~b}$ & 90.95 & $\mathrm{~b}$ & 94.78 & $\mathrm{~b}$ \\
\hline \multirow{4}{*}{ Height } & Summer & 55.25 & $\mathrm{~b}$ & 84.84 & $\mathrm{~b}$ & 104.00 & $\mathrm{~b}$ & 125.84 & $\mathrm{a}$ & 136.82 & $\mathrm{ab}$ & 135.91 & $\mathrm{~b}$ \\
\hline & Autumn & 93.23 & $\mathrm{a}$ & 109.76 & $\mathrm{a}$ & 131.56 & $\mathrm{a}$ & 131.25 & $\mathrm{a}$ & 137.51 & $\mathrm{a}$ & 117.86 & $\mathrm{c}$ \\
\hline & Winter & 32.37 & $\mathrm{c}$ & 57.04 & $\mathrm{c}$ & 46.02 & d & 59.72 & $\mathrm{c}$ & 58.59 & $\mathrm{c}$ & 71.95 & d \\
\hline & Spring & 46.53 & $\mathrm{~d}$ & 64.23 & $\mathrm{c}$ & 93.68 & $\mathrm{c}$ & 113.47 & $\mathrm{~b}$ & 126.73 & $\mathrm{~b}$ & 149.46 & $\mathrm{a}$ \\
\hline
\end{tabular}

Means followed by the same letter, lowerc ase in column and uppercase in line, do not differ among themselves, by Tukey test $(p<0.05)$.

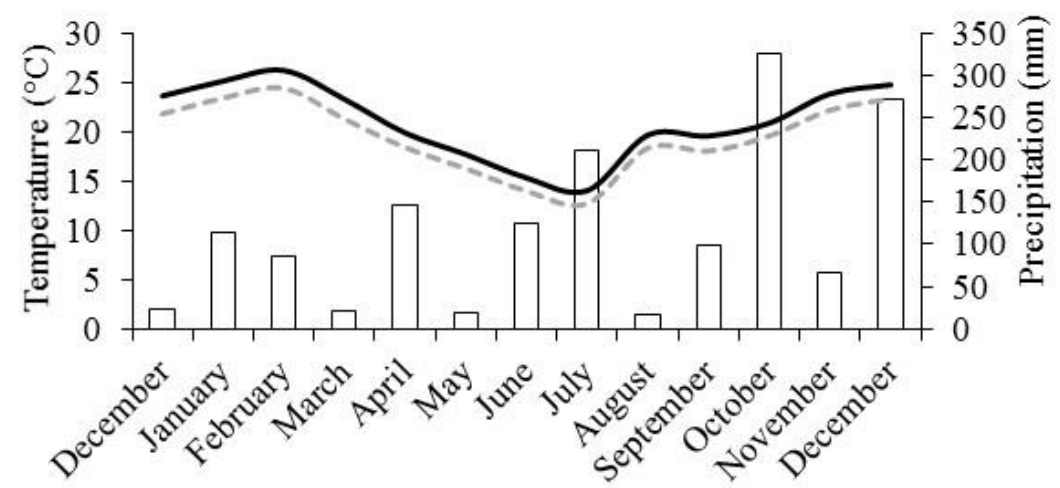

Months of the year

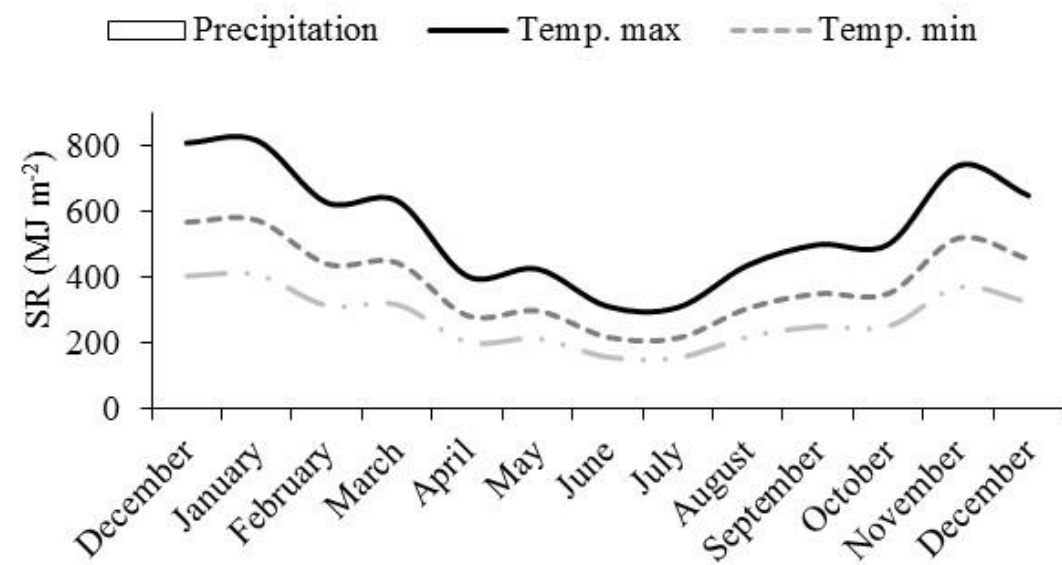

Months of the year

— Full sunlight $\quad----30 \% \quad-\cdot 50 \%$

Fig 1. Average monthly values of maximum temperature (Temp. max), minimum temperature (Temp. min), accumulated precipitation monthly (A), and solar radiation (RS) accumulated monthly in different shading levels $(0,30$ and $50 \%)$ (B) during the period from December 2011 to December 2012. Frederico Westphalen - RS, 2012. 
Table 2. Developments of interactions between levels of shading x DABS for the dry matter of branches $\left(\mathrm{DBM} g\right.$ plant $\left.{ }^{-1}\right)$, leaf area $\left(\mathrm{LA} ; \mathrm{cm}\right.$ plant $\left.^{-1}\right)$, and plant height $(\mathrm{cm})$. Frederico Westphalen - RS, 2012.

\begin{tabular}{|c|c|c|c|c|c|c|c|c|c|c|c|c|c|}
\hline \multirow{2}{*}{ Var. } & \multirow{2}{*}{ Shading $(\%)$} & \multicolumn{12}{|c|}{ Days after the beginning of the season (DABS) } \\
\hline & & 15 & & 30 & & 45 & & 60 & & 75 & & 90 & \\
\hline \multirow{3}{*}{ DBM } & 0 & 3.37 & a & 14.57 & $\mathrm{a}$ & 18.69 & $\mathrm{a}$ & 39.08 & $\mathrm{a}$ & 43.98 & $\mathrm{a}$ & 35.23 & $\mathrm{a}$ \\
\hline & 30 & 4.24 & a & 7.88 & $\mathrm{~b}$ & 19.21 & a & 18.47 & $\mathrm{~b}$ & 25.84 & $\mathrm{~b}$ & 32.88 & $\mathrm{a}$ \\
\hline & 50 & 2.08 & a & 8.07 & $\mathrm{~b}$ & 11.44 & $\mathrm{~b}$ & 22.80 & b & 22.09 & $\mathrm{~b}$ & 37.37 & $\mathrm{a}$ \\
\hline \multirow{3}{*}{ LA } & 0 & 10.53 & $a$ & 38.12 & $\mathrm{a}$ & 43.77 & $\mathrm{~b}$ & 72.18 & $\mathrm{a}$ & 70.60 & $\mathrm{a}$ & 80.33 & $\mathrm{~b}$ \\
\hline & 30 & 15.40 & a & 25.17 & $\mathrm{~b}$ & 59.94 & $\mathrm{a}$ & 63.35 & a & 76.65 & $\mathrm{a}$ & 107.04 & $\mathrm{a}$ \\
\hline & 50 & 9.70 & $\mathrm{a}$ & 23.98 & $\mathrm{~b}$ & 45.94 & $\mathrm{~b}$ & 74.44 & $\mathrm{a}$ & 67.74 & $\mathrm{a}$ & 99.62 & $\mathrm{a}$ \\
\hline \multirow{3}{*}{ Height } & 0 & 55.54 & $\mathrm{a}$ & 83.66 & $\mathrm{a}$ & 89.83 & $\mathrm{~b}$ & 108.40 & $\mathrm{a}$ & 122.38 & $\mathrm{a}$ & 113.62 & $\mathrm{~b}$ \\
\hline & 30 & 55.40 & $\mathrm{a}$ & 74.69 & b & 101.04 & $\mathrm{a}$ & 107.14 & $\mathrm{a}$ & 115.75 & $\mathrm{a}$ & 121.81 & $\mathrm{a}$ \\
\hline & 50 & 59.61 & a & 78.55 & $\mathrm{a}$ & 90.58 & $\mathrm{~b}$ & 107.17 & $\mathrm{a}$ & 106.60 & $\mathrm{~b}$ & 120.96 & $a b$ \\
\hline
\end{tabular}

Means followed by the same letter, lowerc ase in column and uppercase in line, do not differ among themselves, by Tukey test $(p<0.05)$.
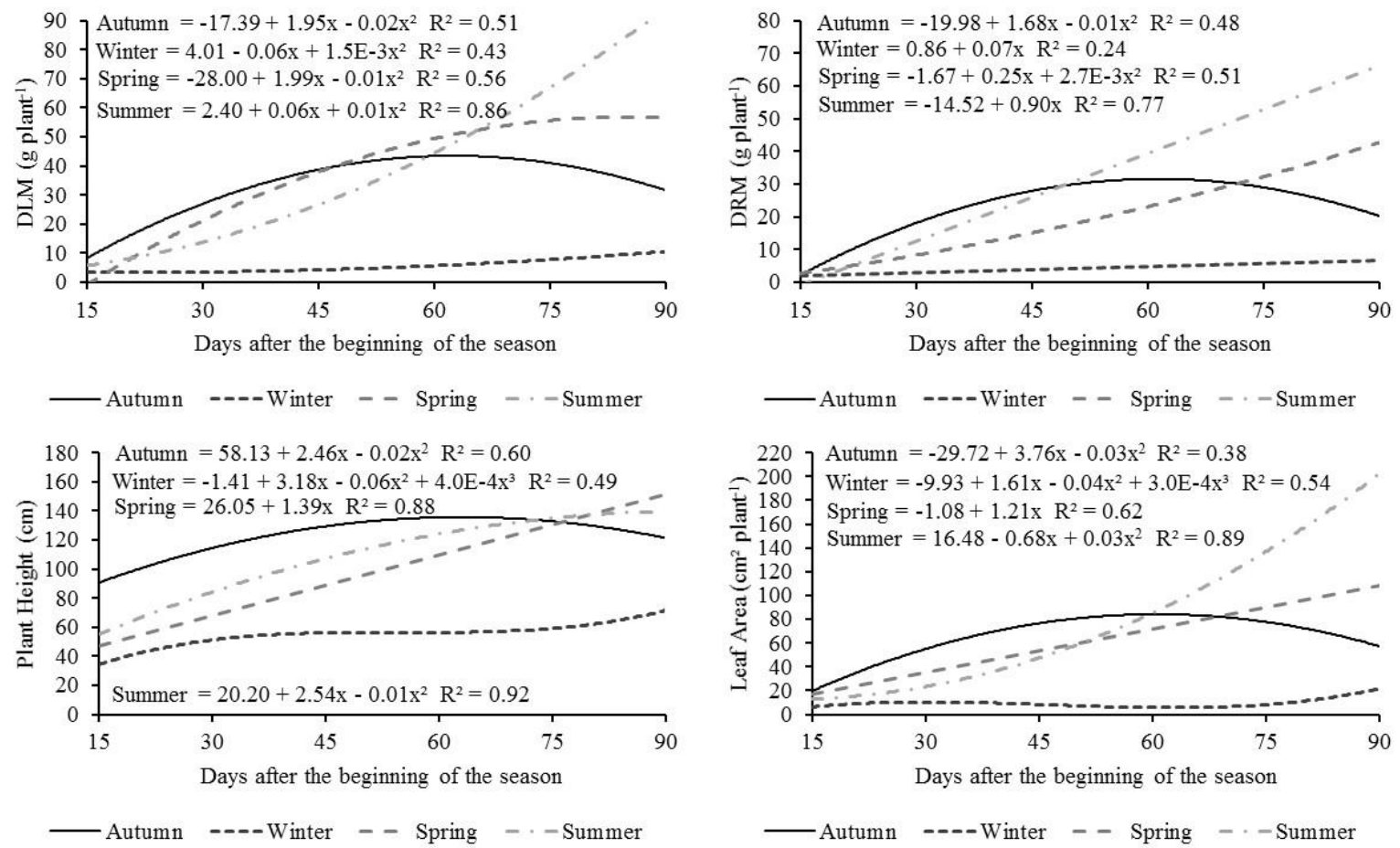

Fig 2. Regression equations for dry leaf matter (DLM; A), dry branch matter (DBM; B), plant height (C), and leaf area (D) of Aloysia triphylla along the days after the beginning of the season. Frederico Westphalen - RS, 2012.

Table 3. The interaction between season $x$ shading levels for dry leaf matter (DLM; g plant $\left.{ }^{-1}\right)$ and dry branch matter (DBM $g$ plant $\left.{ }^{-1}\right)$. Frederico Westphalen - RS, 2012.

\begin{tabular}{|c|c|c|c|c|c|c|c|c|c|}
\hline \multirow{2}{*}{ Variables } & \multirow{2}{*}{ Shading } & \multicolumn{8}{|c|}{ Season of the year } \\
\hline & & Summer & & Autumn & & Winter & & Spring & \\
\hline \multirow{3}{*}{ DLM } & 0 & 43.36 & $\mathrm{aB}$ & 38.19 & $\mathrm{aB}$ & 8.08 & $\mathrm{aC}$ & 52.07 & $\mathrm{aA}$ \\
\hline & 30 & 42.81 & $\mathrm{aA}$ & 33.23 & $\mathrm{aB}$ & 5.17 & $\mathrm{aC}$ & 29.09 & $\mathrm{bB}$ \\
\hline & 50 & 40.59 & $\mathrm{aA}$ & 24.79 & $\mathrm{bC}$ & 4.50 & $\mathrm{aD}$ & 34.29 & $\mathrm{bB}$ \\
\hline \multirow{3}{*}{ DBM } & 0 & 32.89 & $\mathrm{aA}$ & 28.23 & $\mathrm{aB}$ & 5.97 & $\mathrm{aC}$ & 36.15 & $\mathrm{aA}$ \\
\hline & 30 & 30.90 & $\mathrm{aA}$ & 22.38 & $\mathrm{bB}$ & 3.31 & $\mathrm{aD}$ & 15.76 & $\mathrm{bC}$ \\
\hline & 50 & 34.40 & $\mathrm{aA}$ & 16.94 & $\mathrm{cB}$ & 3.72 & $\mathrm{aC}$ & 14.18 & $\mathrm{bB}$ \\
\hline
\end{tabular}

Means followed by the same letter, lowercase in column and uppercase in line, do not differ among themselves, by Tukey test $(p<0.05)$. 

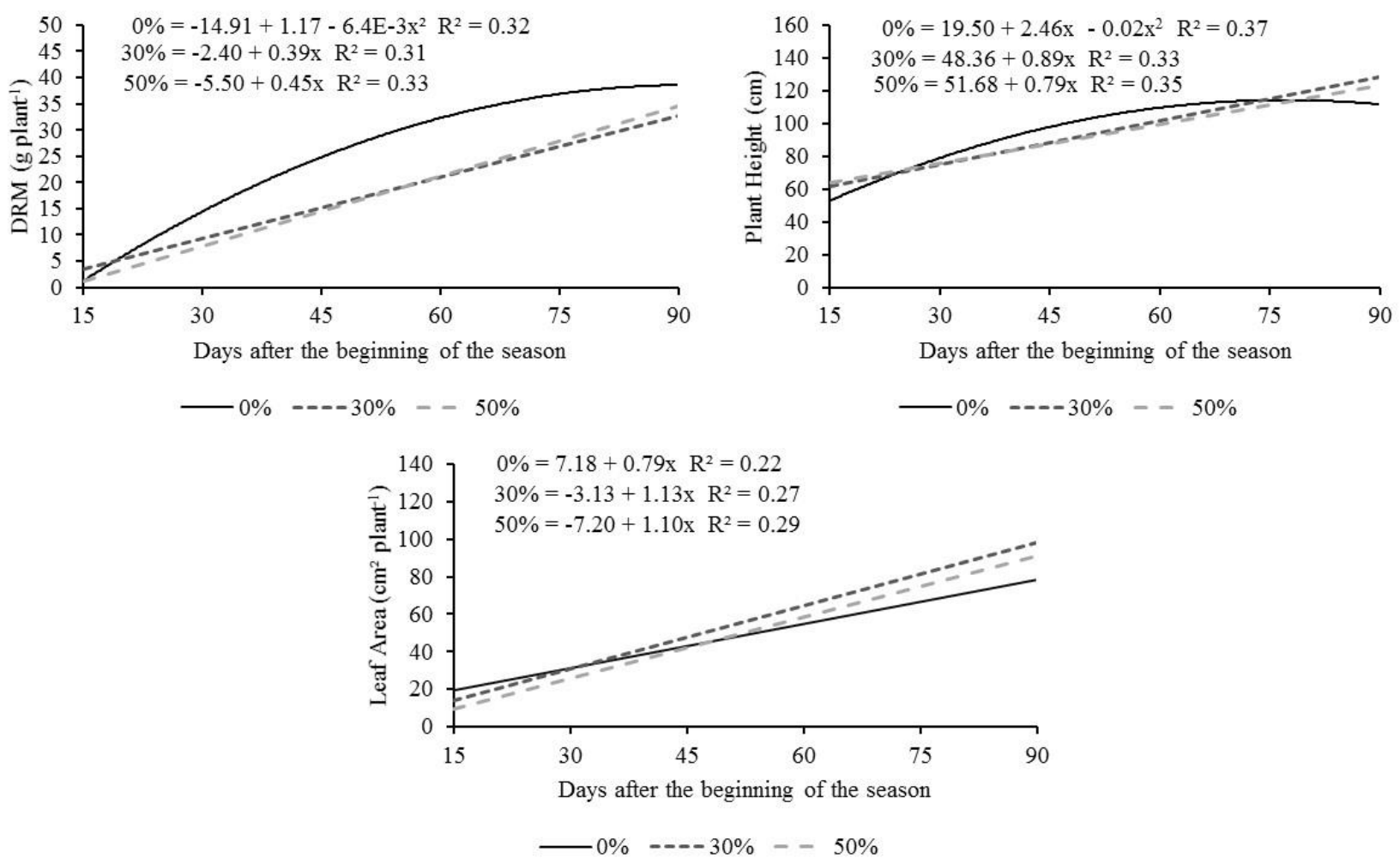

Fig 3. Regression equations for dry branch matter (DBM; A), plant height (B), and leaf area (C) of Aloysia triphylla along the days after the start of the season in each shading level. Frederico Westphalen - RS, 2012.

Melissa officinalis, observed an increase in leaf area under $25 \%$ shading. It is interesting to note that often the increase in leaf area does not imply an increase in DLM, which was observed in this study. Leaves that develop in full sunlight, tends to be thicker compared to plants which develop in shadier environment. This characteristic may be related to the presence of larger mesophyll cells due to the acclimatization if a plant (Taiz and Zeiger, 2013).

The responses of plants to shade are varied according to the species and amount of attenuated radiation. Chang et al. (2008) observed a significant reduction of total dry biomass production of Ocimum basilicum when subjected to treatments with lower levels of light radiation. Sales et al. (2009) found a higher dry matter accumulation of leaves for Hyptis marrubioides, in environments with $0 \%$ shading, compared to $40 \%$ and $80 \%$ shading. Pinto et al. (2007) studying Aloysia gratissima, observed a $25 \%$ reduction in dry matter in leaves which received $80 \%$ of shading in relation to full sunlight and $35 \%$ compared to $40 \%$ shading. Gomes et al. (2009) studying Lippia citriodora, observed that the total dry matter in full sun was higher compared to the treatments under 50 and $25 \%$ total light.

\section{Plant height and total dry matter for leaves and branches is altered by shading levels}

Plant height presented different responses, and did not show the same trend over the collections (Table 2). In the literature, divergent responses were observed as to the effect of shadowing on plant height, this variation that depends on specific species, shading level, cultivation area, and meteorological conditions. Morelli and Rubertti (2000) emphasize that the growth in height is one of the first responses to shading, and this behavior occurs due to an attempt of the plant to find light and improve photosynthetic processes.

The medicinal species Hyptis marrubioides (Sales et al., 2009) and Baccharis trimera (Silva et al., 2006) presented higher plant height in shaded treatments; however, the increase in height in environments with high luminous restrictions, can result etiolated plants (Franco and Dillenburg, 2007), compromising the shoot and also the issue of side branches. Considering that one of the main objectives of Aloysia triphylla cultivation is the extracted essential oil from the leaves, the variable DLM is considered one of the most important.

\section{Leaf area of Aloysia triphylla is altered by shading levels}

By analyzing the variable DLM in the interaction season $\mathrm{x}$ shading levels, higher values in spring were observed, in the treatment without light restrictions (Table 3). In the treatment of $50 \%$ shading, values of dry branch matter were higher in the summer. Comparing the shading levels in each season, the treatment submitted to shading level of $30 \%$ did not differed from the $0 \%$ level, except in the spring season. In summer and winter, both shading levels showed no significant differences.

In spring, the reduction of the incidence solar radiation caused by the mesh was not adequate, since the amount of solar radiation was insufficient for the appropriate development of the plant species, this is likely the reason why full sunlight showed the best results. In summer, the levels of $30 \%$ and $50 \%$ shading showed, on average, higher values than other seasons (Table 3 ).

In the quantitative analysis (Fig. 2), low increments in all variables were observed throughout the winter season; moreover, it was possible to identify a more pronounced reduction in the values of all variables from 60 DABS in the fall. 
This result may be related, in addition to autumn frosts, to low and irregular rainfall in the May month 2012 (Fig. 1), in which only $20 \mathrm{~mm}$ were recorded; this value is considered insufficient for the adequate crop growth. These factors contributed to the overlapping of curves for the spring and summer seasons, especially from 60 DABS. In the same context, Brant et al. (2008) found slow growing Aloysia triphylla plants and reducing the essential oil content due to the presence of adverse weather conditions (rainfall, humidity and temperature).

\section{Shading levels affected the accumulation of biomass in the different seasons of the year}

The interaction between shading levels and DABS (Fig 3) showed greater increases in DBM (A) and plant height (B) in the higher levels of incident solar radiation ( $0 \%$ shading), however, a reduction in values in last collections. This response was not observed in the shading levels of 30 and $50 \%$. Despite lower growth rates, there was greater stability in the growth of plants subjected to shading, likely due to interactions that shading meshes have on the cultivation environment. Muller et al. (2014) highlighted this interaction in agroforestry systems (consortium), in which some tree species cause shading in annual crops.

Caron et al. (2014c) found that the biomass of Ilex paraguariensis species (leaves + branches) is higher in the full sun cultivation compared to shading. However, taking into account the content of some nutrients in the plant (calcium, magnesium and phosphorus), minor variations were observed (higher production stability) in the radiation reduction conditions ( $85 \%$ shading) for different seasons. This indicates a more constant metabolic activity of the studied plants, which is an important factor in the final quality of the product. The amount of leaf biomass produced by Aloysia triphylla species reflects directly in the yield of its essential oil; therefore, studies that show information about the most appropriate environment and most ideal month for cultivation regarding the production of leaves may have significant relevance for producers and those looking to improve the management of this species.

\section{Materials and methods}

\section{Study area and experimental design}

The study was conducted in an experimental greenhouse in the city of Frederico Westphalen, Rio Grande do Sul, Brazil, with the geographic coordinates $27^{\circ} 23^{\prime} 26^{\prime \prime} \mathrm{S}$; 53 $3^{\circ} 25^{\prime} 43^{\prime \prime} \mathrm{W}$, $461 \mathrm{~m}$ asl. According to the Köppen climate classification (Alvares et al., 2013), the climate of region is $\mathrm{Cfa}$, ie, humid subtropical with an average annual temperature of $19.1{ }^{\circ} \mathrm{C}$, varying with maximum of $38^{\circ} \mathrm{C}$ and minimum of $0^{\circ} \mathrm{C}$. The soil of the experimental area belongs to the region of Passo Fundo, Brazil, and is classified as Oxisol distrofic typical, clayey, deep, and well drained (Embrapa, 2006).

The experimental design was a randomized complete block, arranged in a factorial layout $(3 \times 4 \times 6)$ with four replications. We simulated three different solar radiation levels with black polyethylene meshes, fixed $1.0 \mathrm{~m}$ above the evaluation plants. The following treatments were made: $0 \%$ of shading (without meshes over the plants), $30 \%$ of shading $(70 \%$ transmissivity meshes), and $50 \%$ of shading (50\% transmissivity meshes). These shading conditions have been imposed along all evaluation period. The evaluations periods have been carried out in four seasons (summer, autumn, winter, and spring). Each season six collections (15, 30, 45,
60,75 and 90 days after the beginning of the season) were performed. The plant collection was performed after the beginning of each season, with the following dates: (Summer: 21 december; Autumn: 20 march; Winter: 20 june; Spring: 22 september). All evaluations were performed in 2012, since in the first evaluation periods the plants had 65 days after transplanting to the greenhouse; and the last evaluation period the plants showed 315 days after transplanting, throughout the four seasons of the year. The meteorological conditions during the evaluation periods can be seen in the Fig 1.

\section{Experimental management}

Each experimental unit consisted of an Aloysia triphylla plant, with a spacing of $0.8 \mathrm{~m}$ between plants and $1.0 \mathrm{~m}$ between rows, totaling 72 evaluation plants. The plants were originally produced from stem cuttings with were subjected to an application of indole-butyric acid at $1500 \mathrm{mg} \mathrm{L}^{-1}$ aiming to facilitate plant rooting. The stem cuttings were between 15 $\mathrm{cm}$ to $20 \mathrm{~cm}$ in length, and were cultivated in trays with 96 medium size tubes with a mixture of commercial substrate and vermiculite $(1: 1)$, during 60 days. These plants were later transplanted in a greenhouse on 23 November 2011.

The collect of plants on the $4^{\text {th }}$ of January 2012, and finished at the end of the spring season in 2012. It should be noted that for the determination of biomass and morphological parameters, the same groupings of plants were used for evaluation in each season. After each collection, the branches and leaves of the each plant were separated and placed into pre-identified individual paper sacks. The sacks were then sent into a forced circulation oven at $60^{\circ} \mathrm{C}$ until a consistent mass was obtained. The samples were later weighed on a precision balance in order to obtain the dry mass of each component.

The plant height was measured with the aid of a measuring tape, being that four replications for each treatment were performed, measuring from the soil base to the last leaf spandid. The leaf area of plants was obtained with the use of a leaf area meter, model 3100 LI, LI-COR, NE, USA. For the leaf area determination homogeneous samples of upper, middle and bottom leaves of the plant were collected, in order to obtain a representative leaf area.

The values of incident global solar radiation and average air temperature were obtained from the Meteorological Station of the Meteorology National Institute (MSMNI) which was situated about $50 \mathrm{~m}$ from the experimental area and linked to the Agroclimatology Laboratory of the Federal University of Santa Maria.

\section{Statistical analysis}

The results were submitted to analysis of variance through the computer program Statistical Analysis System (SAS, 2003). The parameters that demonstrated statistically significant differences at the level of $(p<0.05)$. were compared using regression analysis for the DABS and Tukey's test for the seasons and shading levels.

\section{Conclusion}

The production of the dry matter of leaves and branches, height and leaf area of the species Aloysia triphylla is influenced by shading levels and the seasons of the year. The variables are highly dependent of the seasonality of meteorological elements such as temperature, solar radiation, rainfall and frosts. 
In an environment with $0 \%$ shading, the dry matter production of leaves was $60.8 \%$ higher in the spring, than those observed for the $30 \%$ and $50 \%$ of shading, while this levels resulted higher production in the summer.

We showed that the use of shading screens in order to attenuate the solar radiation in places or seasons where there is high light intensity is an effective method to achieve higher production of leaves, which is important source for the oil production.

\section{Acknowledgments}

The authors wish to acknowledge the National Council for Scientific and Technological Development (CNPq - Brazil) and the Coordination for the Improvement of Higher Education Personnel (CAPES - Brazil) for their financial support.

\section{References}

Alvares CA, Stape JL, Sentelhas PC, Moraes G, Leonardo J, Sparovek G (2013) Köppen's climate classification map for Brazil. Meteorol Z. 22(6):711-728.

Bianculli ML, Aguirrezábal LAN, Pereyra Irujo GA, Echarte MM (2016) Contribution of incident solar radiation on leaves and pods to soybean seed weight and composition. Eur J Agron. 77:1-9.

Brant RS, Pinto JEB, Bertolucci SKV, Albuquerque CJB (2008) Teor do óleo essencial de cidrão (Aloysia triphylla (L' Hérit) Britton Verbenaceae) em função da variação sazonal. Rev Bras Plantas Med. 10(2):83-88.

Brant RS, Pinto JEB, Bertolucci SKV, Albuquerque CJB (2010) Produção de biomassa e teor do óleo essencial de cidrão em função da adubação orgânica. Hort Bras. 28: 111-114.

Buriol GA, Streck NA, Petry C, Schneider FM (1995) Transmissividade da radiação solar do polietileno de baixa densidade utilizado em estufa. Ciênc Rural. 25(1):1-4.

Buriol GA; Estefanel V, Andriolo JL (2000) Disponibilidade de radiação solar nos meses mais frios do ano para o cultivo do tomateiro no Estado do Rio Grande do Sul. Pesq Agropec Gau. 6(1):113-120.

Caron BO, Perrando ER, Schmidt D, Manfron PA, Behling A, Elli EF, Eloy E. (2014a) Relações fisiológicas em mudas de pata-de-vaca (Bauhinia forficata Link). Rev Bras Plantas Med. 16(2):196-201.

Caron BO, Schmidt D, Manfron PA, Behling A, Eloy E, Busanello C (2014b) Eficiência do uso da radiação solar por plantas Ilex paraguariensis A. St. Hil. cultivadas sob sombreamento e a pleno sol. Ci F1. 24(2):257-265.

Caron BO, Dos Santos DR, Schmidt D, Basso CJ, Behling A, Eloy E, Bamberg R (2014c) Biomassa e acúmulo de nutrientes em Ilex paraguariensis A. St. Hil Ci Fl. 24(2):267-276.

Castro EMD, Pinto JEBP, Melo HCD, Soares AM, Alvarenga AAD, Lima Júnior EC (2005) Aspectos anatômicos e fisiológicos de plantas de guaco (Mikania glomerata Sprengel) submetidas a diferentes fotoperíodos. Hort Bras. 23(3):846-850.

Chang X, Alderson PG, Wright CJ (2008) Solar irradiance level alters the growth of basil (Ocimum basilicum L.) and its content of volatile oils. Environ. Exp Bot. 63(3):216223.

Cockshull KE, Graves CJ, Cave CRJ (1992) The influence of shading on yield of glasshouse tomatoes. J Hortic Sci. 67(1):11-24.
Cossu M, Murgia L, Ledda L, Deligios PA, Sirigu A, Chessa F, Pazzona A (2014) Solar radiation distribution inside a greenhouse with south-oriented photovoltaic roofs and effects on crop productivity. Appl Energy. 133:89-100.

Dario MF, Baby AR, Velasco MVR (2015) Effects of solar radiation on hair and photoprotection. J Photochem Photobiol. B 153:40-246.

Dianat M, Saharkhiz MJ, Tavassolian I (2016) Salicylic acid mitigates drought stress in Lippia citriodora L.: Effects on biochemical traits and essential oil yield. Biocatal Agric Biotechnol. 8:286-293.

Duarte MCT, Leme EE, Delarmelina C, Soares AA, Figueira GM, Sartoratto A (2007) Activity of essential oils from Brazilian medicinal plants on Escherichia coli. J Ethnopharmacol. 111(2):197-201.

Ebadi MT, Azizi M, Sefidkon F, Ahmadi N (2015) Influence of different drying methods on drying period, essential oil content and composition of Lippia citriodora Kunth. J Appl Res Med Aromat Plants. 2(4):182-187.

Elli EF, Cantarelli EB, Caron BO, Monteiro GC, Pavan MA, Pedrassani M, Eloy E (2013) Osmocote no desenvolvimento e comportamento fisiológico de mudas de pitangueira. Com Sci. 4(4):377-38.

Embrapa - Empresa Brasileira de Pesquisa Agropecuária. Sistema Brasileiro de Classificação de Solos. 2 ed. Rio de Janeiro: Embrapa-SPI. 2006. 412p.

Franco AMS, Dillenburg LR (2007) Ajustes morfológicos e fisiológicos em plantas jovens de Araucaria angustifólia (Bertol.) Kuntze em resposta ao sombreamento. Hoehnea. 34(2):135-144

Garcez Neto AF, Garcia R, Moot DJ, Gobbi KF (2010) Aclimatação morfológica de forrageiras temperadas a padrões e níveis de sombreamento. Rev Bras Zootec. 39(1):42-50.

Gomes PA, de Souza MF, de Souza Junior IT, Junior WGOC, de Figueiredo LS, Martins ER (2009) Influência do sombreamento na produção de biomassa, óleo essencial e quantidade de tricomas glandulares em cidrão (Lippia citriodora Lam.). Biotemas. 22(4):9-14.

Kataria S, Guruprasad KN (2015) Exclusion of solar UV radiation improves photosynthetic performance and yield of wheat varieties. Plant Physiol Biochem. 97:400-411.

Lopes NF, Oliva MA, Cardoso MJ, Gomes MMS, Souza VF (1986) Crescimento e conversão de energia solar em Phaseolus vulgaris submetido a três densidades de fluxo radiante e dois regimes hídricos. Revista Ceres. 33(186):142-114.

Lorenzi H, Matos FJA (2002) Plantas medicinais no Brasil: nativas e exóticas cultivadas. São Paulo: Instituto Plantarum, 512p.

Martins M, Marques OAV, Sazima I (2008) How to be arboreal and diurnal and still stay alive: microhabitat use, time of activity, and defense in Neotropical forest snakes. South. Am J Herpetol. 3(1):58-67.

Meira MR, Martins ER, Manganotti AS (2012) Crescimento, produção de fitomassa e teor de óleo essencial de melissa (Melissa officinalis) sob diferentes níveis de sombreamento. Rev Bras Plantas Med. 14(2):352-357.

Morelli G, Ruberti I (2000) Shade avoidance responses. Driving auxin along lateral routes. Plant Physiol. 122(3):621-626.

Müller MD, Paciullo DSC, Martins CE, da Rocha WSD, de Castro CRT (2014) Desenvolvimento vegetativo de pinhão - manso em diferentes arranjos de plantio em sistemas agrossilvipastoris. Pesq Agropec Bras. 49(7):506514. 
Murchie EH, Pinto M, Horton P (2008) Agriculture and the new challenges for photosynthesis research. New Phytol. 181:532-552.

Paulus D, Valmorbida R, Toffoli E, Nava GA (2013) Teor e composição química do óleo essencial e crescimento vegetativo de Aloysia triphylla em diferentes espaçamentos e épocas de colheita. Revista Ceres. 60(3):372-379.

Pinto JEBP, Cardoso JCW, Castro EM, Bertolucci SK, Melo LA, Dousseau S (2007) Aspectos morfológicos e conteúdo de óleo essencial de plantas de alfazema-do-Brasil em função de níveis de sombreamento. Hort Bras. 25(2):210214.

Pinto JEBP, Bertolucci, SKV (2002) Cultivo e processamento de plantas medicinais. Lavras: UFLA/FAEPE, 169p.

Sales JF, Pinto JEBP, Ferri PH, Silva FG, de Oliveira CBA, Botrel PP (2009) Influência do nível de irradiância no crescimento, produção e composição química do óleo essencial de hortelã-do-campo (Hyptis marrubioides Epl.). Semina: Ciências Agrárias. 30(2):389-396.

SAS LEARNING EDITION. Getting started with the SAS Learning Edition. Cary. 2003. 200p.

Silva FG, Pinto JEBP, Cardoso MDG, Nascimento EA, Nelson DL, Sales JDF, Mol DJDS (2006) Influence of radiation level on plant growth, yield, and quality of essential oil in carqueja. Ciênc Agrotec. 30(1):52-57.
Suarez S, Gil A, Lorenzo E (2003) Aloysia citriodora: morphology and density of gladular trichomes, and its relationships with essential oil content. In: SIMPÓSIO BRASILEIRO DE ÓLEOS ESSENCIAIS, Campinas: Instituto Agronômico, p.78.

Zhang SB, Hu H, Xu K, Li ZR, Yang YP (2007) Flexible and reversible responses to different irradiance levels during photosynthetic acclimation of Cypripedium guttatum. J Plant Physiol. 164:611-620

Taiz L, Zeiger E (2013) Fisiologia vegetal. 3.ed. Porto Alegre: Artmed, 918p.

Zeppenfeld CC et al. (2014) Physiological and biochemical responses of silver catfish, Rhamdia quelen, after transport in water with essential oil of Aloysia triphylla (L'Herit) Britton. Aquaculture. 418:101-107. 